\title{
Chia (Salvia hispanica) harvest residue induces cytokine expression in rabbits
}

\section{El residuo de la cosecha de chia (Salvia hispanica) induce la expresión de citocinas en conejos}

\author{
Mónica Ilsy Jiménez-Rojas ${ }^{1}$, Roberto Vázquez-Euán ${ }^{2}$, Héctor Magaña-Sevilla ${ }^{1}$, Gabriel de Jesús Azcorra \\ Perera ${ }^{1}$, Rossana Rodríguez Canul ${ }^{3}$, Roberto Zamora-Bustillos ${ }^{1 *}$. \\ ${ }^{1}$ Instituto Tecnológico de Conkal, Yucatán. Avenida Tecnológico s/n. CP. 97345. Conkal, Yucatán, México. \\ ${ }^{2}$ Universidad de Sonora. Departamento de Investigaciones Científicas y Tecnológicas. Blvd. Luis Encinas y Rosales s/n, Col. \\ Centro. CP. 83000. Hermosillo, Sonora, México. \\ ${ }^{3}$ Centro de Investigación y de Estudios Avanzados del IPN - Unidad Mérida. Antigua carretera A Progreso Km 6, Cordemex, \\ CP. 97310. Mérida, Yucatán. México. \\ ${ }^{*}$ Corresponding author: roberto.zamora @itconkal.edu.mx
}

Scientific article received: February 20, 2017 accepted: June 14, 2017

\begin{abstract}
The seed of chia plant (Salvia hispanica) is characterized by a high content of polyunsaturated fatty acids, which is an important source of $\alpha$-linolenic acid for human and animal consumption. During the harvest of the seed, waste is generated that contains remnants of leaves, stems and some seeds, which is generally discarded. The objective of the present work was to evaluate the effect of chia seed residue (CSR) on protein expression of the rabbit immune system, when added as a supplement in the diets of animals deliberately induced to an intestinal infection. Twenty rabbits (New Zealand $\times$ California) were randomly distributed in five treatments and fed five diets with different percentages of CSR inclusion (0,10,20,30 and 40\%). Quantification of the relative expression of the anti-inflammatory Interleukin-10 (IL-10) and Tumor Necrosis Factor (TNF- $\alpha$ ) genes showed that as CSR inclusion levels increased up to $40 \%$, mRNA expression of IL-10 increased significantly (22.4-fold) with respect to the control, while TNF- $\alpha$ mRNA expression was inversely proportional, where a significant increase $(7.47$-fold) in mRNA expression was found in the control group. It is concluded that the indirect inclusion of $\alpha$-linolenic acid through the consumption of CSR induces a positive response in the immune system of the rabbits and represents an alternative for the formulation of rations with nutraceutical effects.
\end{abstract}

Key words: Feeding, $\alpha$-linolenic acid, IL-10, TNF- $\alpha$, Relative expression.

RESUMEN. La semilla de la planta de la chía (Salvia hispánica), se caracteriza por su alto contenido de ácidos grasos poliinsaturados, por lo que es una fuente importante de ácido $\alpha$-linolénico para consumo humano y animal. Durante la cosecha de la semilla, generan residuos que contiene remanentes de hojas, tallos y semillas, que son desechadas. El objetivo del presente trabajo fue evaluar el efecto del residuo de la cosecha de semilla de chía (RCS) sobre la expresion de proteínas del sistema inmune de conejos, al añadirlo como complemento en las dietas de animales inducidos con infección intestinal. Se distribuyeron al azar veinte conejos (Nueva Zelanda $\times$ California) en cinco tratamientos y se alimentaron con cinco dietas con porcentajes de inclusión de RCS de 0,10,20, 30 y 40\%. La cuantificación de la expresión relativa de los genes interleuquina-10 (IL-10) y factor de necrosis tumoral (TNF- $\alpha$ ) mostraron que conforme aumentaron los niveles de inclusión RCS hasta $40 \%$, también aumentó de forma significativa la expresión relativa de IL-10 hasta 22.4 veces con respecto al control, mientras que la expresión relativa de la TNF- $\alpha$ fue inversamente proporcional, presentando la mayor expresión relativa el grupo control con 7.47, por lo que la inclusión indirecta de ácido $\alpha$-linolénico a través del consumo de RCS inducen una respuesta positiva en el sistema inmune de los conejos y representa una alternativa para la formulación de raciones con efectos nutracéuticos.

Palabras clave: Alimentación, Ácido $\alpha$-linolénico, IL-10, TNF- $\alpha$, Expresión relativa. 


\section{INTRODUCTION}

There has been growing interest in recent years in the study of oleaginous plants such as chia (Salvia hispanica) due to the properties of its seed, which is a rich source of polyunsaturated fatty acids (Heuer et al. 2002) and contains compounds such as myricetin, quercetin, kaempferol and caffeic acid with high antioxidant content (Capitani et al. 2012). This seed has already been used in diets for poultry (Komprda 2013), to enrich the production of goat's milk (Martínez 2013) and in rabbit diets (Peiretti and Meineri 2007).

Chia seed residue (CSR) is the by-product generated during the harvest of the seed, usually composed of leaves, stems and seeds that escaped the sieve. There are no studies that provide knowledge on the use of CSR as a nutritional source (Ramírez et al. 2012), but there is evidence of the use of seed for animal consumption because of its high fiber and fatty acid contents, especially $\alpha$-linolenic acid (Coates et al. 1996).

The benefits provided by the inclusion of $\alpha$ linolenic acids in the human diet are documented; they strengthen the immune system by means of decreasing the production of mediators and regulators (PGE 2 , LTB4, TXA2, IL-1 $\beta$, IL-6, and TNF- $\alpha$ ) of inflammatory processes (Jeong 2010). The effect of $\alpha$-linolenic fatty acids on inflammatory processes occurs through their incorporation into cell membranes, serving as substrates for the metabolism of eicosanoids, which causes the production of metabolites such as EPA and DHA, with antiinflammatory properties (Kalupahana et al. 2011).

Cytokines are extracellular and water-soluble polypeptides that range in size from 8 to $30 \mathrm{kDa}$. Although they are redundant in their activities, they are usually linked to specific receptors that trigger cascade signals and activate intracellular messengers that regulate gene transcription (Jun-Ming and Jianxiong 2007). By influencing cytokines in cellular processes such as differentiation, proliferation and longevity of the cell, they also regulate the production and activity of other cytokines, which can increase or attenuate an inflammatory response
(Raeburn et al. 2002). Some cytokines may have pro-(Th1) or anti-inflammatory (Th2) actions, in tune with the microenvironment in which they are found. Among those considered proinflammatory, we have the interleukins (IL) 1, 2, 6, 7 and TNF (Tumor Necrosis Factor), and the anti-inflammatory agents IL-4, IL-10, IL-13 and TGF- $\beta$ (Transforming Growth Factor $\beta$ ) (Zhang and An 2007). Due to the above, the aim of this research was to evaluate CSR potential as an animal feed alternative and the effect of its $\alpha$-linoleic fatty acid content on animal welfare, through the immune system response of rabbits and the analysis of the expression of cytokine genes IL10 and TNF- $\alpha$, after an acute infection induced by acute colitis.

\section{MATERIALS AND METHODS}

The experiment was carried out in february 2015 at the San Miguel rabbit farm in the municipality of Seyé, Yucatán, Mexico, located at $20^{\circ} 53^{\prime} 03.1^{\prime \prime} \mathrm{N}, 89^{\circ} 22^{\prime} 36.0^{\prime \prime} \mathrm{W}$.

\section{Experimental design}

The experimental lot consisted of 20 recentlyweaned rabbits (New Zealand $\times$ California), with weights of $500 \pm 10 \mathrm{~g}$. Four experimental treatments with replicates of 4 animals and a control with $0 \%$ CSR inclusion were used.

\section{Diet formulation}

The rabbits were fed diets prepared with CSR in the form of pellets following the specifications of Rodríguez-Abello et al. (2016), at 10\%, 20\%, $30 \%$ and $40 \%$ inclusion levels. The diets were formulated in such a way that they were isoenergetic and isoproteic, according to the requirements described for fattening rabbits in intensive production systems (De Blas and Mateos 2010) (Table 1). The diets were subjected to bromatological analysis to determine if they meet the nutritional requirements for rabbit development. The control diet was a PURINA ${ }^{\circledR}$-brand commercial rabbit feed, without CSR inclusion. During the 10 weeks of evaluation, the rabbits were weighed individually at 
Table 1. Chemical composition of diets containing $10,20,30$ and $40 \%$ chia

\begin{tabular}{llllll} 
seed residue. & \multicolumn{5}{c}{ Diets } \\
\cline { 3 - 6 } Ingredient & \multirow{2}{*}{ Control } & \multicolumn{5}{c}{ Ch30 } & Ch40 \\
\cline { 3 - 6 } & 8.000 & 8.000 & 8.000 & 7.380 & 8.000 \\
Maize & 0.380 & 5.000 & 5.000 & 5.000 & 5.000 \\
Sorghum & 30.960 & 10.860 & 0 & 0 & 0 \\
Sehydrated Alfalfa & 3.990 & 8.460 & 10.430 & 9.720 & 10.650 \\
Canola pasta & 4.000 & 4.000 & 4.000 & 4.000 & 4.000 \\
Soybean husk & 10.000 & 10.000 & 8.610 & 0 & 0 \\
Wheat bran & 35.000 & 35.000 & 35.000 & 35.000 & 24.05 \\
Chia seed residue & 0 & 10.000 & 20.000 & 30.000 & 40.000 \\
Molasses & 4.000 & 5.000 & 5.000 & 5.000 & 5.000 \\
Acidified fatty acids & 1.720 & 0.500 & 0.500 & 0.500 & 0.770 \\
Calcium carbonate & 0.700 & 1.990 & 2.320 & 2.270 & 1.610 \\
Sodium chloride & 0.5000 & 0.700 & 0.700 & 0.700 & 0.500 \\
Calcium orthophosphate & 0.150 & 0 & 0 & 0 & 0 \\
Methionine 84\% & 0.100 & 0.059 & 0.023 & 0 & 0 \\
Lysine 70\% & 0.079 & 0.123 & 0 & 0 & 0 \\
Choline & 0.030 & 0.030 & 0.030 & 0.030 & 0.030 \\
Vitamin premix & 0.100 & 0.100 & 0.100 & 0.100 & 0.100 \\
Mineral premix & 0.055 & 0.055 & 0.055 & 0.055 & 0.055 \\
Compactant & 0.100 & 0.100 & 0.100 & 0.100 & 0.100 \\
Antioxidant & 0.100 & 0.100 & 0.100 & 0.100 & 0.100 \\
Antifungal & 0.010 & 0.010 & 0.010 & 0.010 & 0.010 \\
Coccidiostat & 0.020 & 0.020 & 0.020 & 0.020 & 0.020 \\
\hline
\end{tabular}

the beginning and after the experiment at weekly intervals, with a digital scale (Ohaus ${ }^{\circledR}$ Model CKW6R55) of $6 \mathrm{~kg}$ with error $\pm 10 \mathrm{~g}$. Each rabbit was given $150 \mathrm{~g} \mathrm{~d}^{-1}$ of feed and water with ad libitum access, recording daily feed consumption and rejection.

\section{Fatty acid analysis of diets}

For the extraction of total lipids, we used $100 \mathrm{~g}$ of feed, which were dried and subjected to extraction by the Soxhlet method, with a chloroform/methanol mixture $(1: 2 \mathrm{v} / \mathrm{v}$ ) (Halim et al. 2012). The fatty acids were derivatized to methyl esters with $2 \mathrm{M}$ of an ethanolic solution of potassium hydroxide. The methyl esters were quantified by gas chromatography with a Perkin Elmer (Autosystem) unit, equipped with a flame ionization detector and Innowax capillary column (Thomas Scientific (C) (30 m $x 0.320 \mathrm{~mm}$ ), with nitrogen $\left(\mathrm{N}_{2}\right)$ as carrier gas. The temperature of the injector was $250{ }^{\circ} \mathrm{C}$ and of the detector $300{ }^{\circ} \mathrm{C}$. The oven temperature program was $4 \mathrm{~min}$ at $150{ }^{\circ} \mathrm{C}$ with a ramp of $5^{\circ} \mathrm{C}$ per minute up to $190{ }^{\circ} \mathrm{C}$ with a ramp of $2{ }^{\circ} \mathrm{C}$ per minute up to $250{ }^{\circ} \mathrm{C}$. The injection volume was 2 $\mu \mathrm{L}$ per sample. The fatty acids were quantified as percentages of total fatty acids. The identification of the fatty acid profile was made with external standards (Supelco ${ }^{\circledR} 37$ Component FAME Mix).

\section{Colitis induction}

Based on previous reports by Best et al. (2012) and Hutton et al. (2013), when the animals reached week 11 , acute colitis was induced in them for three days by giving them a $28 \mathrm{mg}$ oral dose of the antibiotic Clindamycin (Pet Health $\left.{ }^{\circledR}\right)$. On the fourth day, all the animals of the four treatments plus the control group presented the symptomatology of acute colitis caused by Clostridium sp.

\section{Slaughter and sample preservation}

In the order in which the animals were presenting symptoms of colitis, they were sedated with an intramuscular dose of ketamine $(50 \mathrm{mg}$ $\mathrm{kg}^{-1}$ ), and then slaughtered by decapitation, after supervision of an ethics committee following the official Mexican standard (NOM-033-SAG/ZOO2014). Subsequently, the colon's intermediate re- 
Table 2. Oligonucleotides used for real-time PCR analysis.

\begin{tabular}{|c|c|c|c|c|}
\hline Cytokines & Size (bp) & Oligonucleotide sequences & $\mathrm{Ta}\left({ }^{\circ} \mathrm{C}\right)$ & GenBank Accession no. \\
\hline HPRT & 265 & $\begin{array}{l}\text { F: 5'- TGATAGATCCATTCCTA -3' } \\
\text { R: 5'- GGTCCGTTTTCACCAGCAG -3' }\end{array}$ & 60 & M31642 \\
\hline IL-10 & 100 & $\begin{array}{l}\text { F: 5'- AGAACCACAGTCCAGC -3' } \\
\text { R: 5'- GGGAGAAATCGGTGACAT -3' }\end{array}$ & 60 & M12845 \\
\hline TNF- $\alpha$ & 100 & $\begin{array}{l}\text { F: 5'- GAGCAGCAACTCCAGA-3 } \\
\text { R: } 5^{\prime}-\text { GGTGCGTGAGAGAGGAAG -3' }\end{array}$ & 58 & AF 169170 \\
\hline
\end{tabular}

bp: base pairs, Ta: annealing temperature

gion was dissected and identified; then, using a scalpel, approximately $0.5-\mathrm{cm}$ tissue sections were cut and placed in sterile tubes with $0.2 \mathrm{ml}$ of RNAlater (Invitrogen ${ }^{\mathrm{TM}}$ ). Samples were stored at $4{ }^{\circ} \mathrm{C}$ for $24 \mathrm{~h}$, and subsequently at $-80{ }^{\circ} \mathrm{C}$ until analysis. All processes used in animals of this experiment were approved by a graduate scientific ethics committee at the Instituto Tecnológico de Conkal.

\section{Total RNA extraction and cDNA synthesis}

Total RNA was isolated with the TRIzol method (Invitrogen ${ }^{\mathrm{TM}}$ ), according to the manufacturer's instructions. The concentration and quality of the RNA in each sample was determined between A260/A280 and A260/A230 nm in a NanoDrop Lite (Thermo Scientific ${ }^{\mathbb{R}}$ ). The integrity of the RNA was confirmed with electrophoresis in $2 \%$ agarose gels for 40 min at $90 \mathrm{~V}$, with 2X RNA Loading Dye (Thermo Scientific ${ }^{\circledR}$ ). Prior to treatment with the DNAse enzyme, all samples were homogenized at $500 \mathrm{ng}$ in a volume of $20 \mu \mathrm{L}$. To eliminate any contamination of genomic DNA, approximately 2000 ng of RNA was treated with the DNase I enzyme (TURBO DNA-free ${ }^{T M}$, Ambion ${ }^{\circledR}$ ), according to the manufacturer's instructions. For cDNA synthesis, $10 \mu \mathrm{L}$ of DNase-treated RNA was used with the RevertAid First Strand ${ }^{\circledR}$ kit (Thermo Scientific ${ }^{\circledR}$ ). The reaction was carried out in a thermal cycler (Techne ${ }^{R}$ ), incubating at $65{ }^{\circ} \mathrm{C}$ for $5 \mathrm{~min}, 25{ }^{\circ} \mathrm{C}$ for $5 \mathrm{~min}, 42{ }^{\circ} \mathrm{C}$ for $60 \mathrm{~min}$ and finally $70{ }^{\circ} \mathrm{C}$ for 5 $\min$ to terminate the reaction.

\section{Oligonucleotide design and validation for RT- qPCR}

Oligonucleotides were designed for the IL-
10 and TNF- $\alpha$ genes with the Fast-PCR program, taking as reference the sequences for these rabbit genes reported in GenBank (D84217 and M12845). The pair of oligonucleotides for the housekeeping gene HPRT (hypoxanthine phosphoribosyl transferase) was designed by Godornes et al. (2007) (Table 2). For the validation of the designed oligonucleotides, a standard curve was generated to determine the difference in the predicted amount between a test sample and a calibrator sample. For this, the cDNA of five representative samples of the treatments (200 ng concentration) was used to prepare the calibration curves for each of the genes. For the real-time PCR reaction, a calibration curve was generated from a series of seven $1 / 10$ dilutions of the cDNA (initial concentration of $200 \mathrm{ng}$ ) in triplicate. PCR efficiency was calculated using the equation: $E \%=\left(101 /\right.$ slope $\left.^{-1}\right) \times 10$ (Radonic et al. 2004) (Table 3). Data were analyzed with iQ5 optical system software ver.2 (Bio-Rad).

Table 3. Data of the calibration curves for IL-10, TNF- $\alpha$ and the housekeeping gene, HPRT.

\begin{tabular}{lllll}
\hline Cytokines & $\mathrm{R}^{2}$ values & PCR efficiency & Slope & Mean $\mathrm{E}^{2}$ \\
\hline IL-10 & 0.998 & 1.000 & -3.322 & 0.492168 \\
TNF- $\alpha$ & 0.994 & 1.082 & -3.139 & 0.791156 \\
HPRT & 0.987 & 1.061 & -3.184 & 0.107973 \\
\hline
\end{tabular}

\section{Analysis by $\mathrm{RT}-\mathrm{qPCR}$}

RT-qPCR analysis was performed in triplicate with the Maximum SYBR ${ }^{\mathrm{R}}$ Green/Fluorescein qPCR kit (Thermo Scientific ${ }^{\circledR}$ ) according to the manufacturer's instructions. The reaction of each sample had a final volume of $25 \mu \mathrm{L}$, constituted by $12.5 \mu \mathrm{L}$ of SYBR Green/Fluorescein (2X), $0.3 \mu \mathrm{M}$ of each oligonucleotide and $2000 \mathrm{ng}$ of RNA. The samples were completed with ultrapure water to 
Table 4. Total composition of fatty acids in diets containing $10,20,30$ and $40 \%$ chia seed residue.

\begin{tabular}{llllll}
\hline Fatty acids & Control & Ch10 & Ch20 & Ch30 & Ch40 \\
\hline Total saturated & $56.29 \pm 0.13$ & $10.06 \pm 2.10$ & $11.2 \pm 2.09$ & $12.19 \pm 2.03$ & $13.09 \pm 2.08$ \\
Total monounsaturated & $43.71 \pm 0.06$ & $5.09 \pm 2.03$ & $6.29 \pm 2.08$ & $7.18 \pm 2.07$ & $7.68 \pm 2.09$ \\
18:2w6 (omega-6) & Traces & $9.92 \pm 0.08$ & $10.16 \pm 0.06$ & $11.33 \pm 0.03$ & $12.74 \pm 0.04$ \\
18:3w6 & Traces & $0.10 \pm 0.03$ & $0.12 \pm 0.05$ & $0.13 \pm 0.02$ & $0.15 \pm 0.06$ \\
18:3w3 Cis (omega-3) & Traces & $46.52 \pm 2.03$ & $49.42 \pm 1.09$ & $52.33 \pm 1.06$ & $53.82 \pm 1.05$ \\
Total Polyunsaturated & Traces & $67.81 \pm 0.10$ & $71.17 \pm 0.38$ & $75.67 \pm 0.10$ & $79.03 \pm 0.29$ \\
\hline
\end{tabular}

A

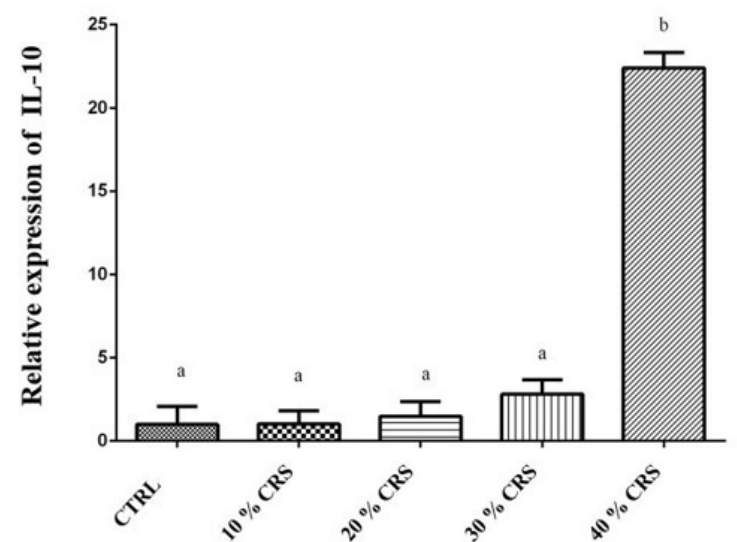

B

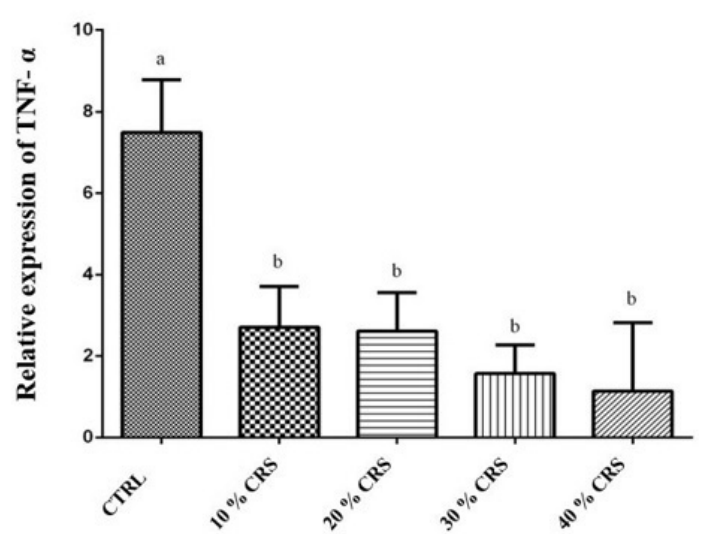

Figure 1. Relative mRNA expression of IL-10(A) and TNF- $\alpha(B)$ genes related to inflammatory process in the middle colon region of rabbits fed chia waste subjected to experimental colitis. CTRL, diet without residues of chia; percentage of chia residue content in diets (10\% CRS, $20 \%$ CRS, 30\% CRS and 40\% CRS). Different letters denote significant differences $(P<0.05)$; values are presented as the mean \pm standard deviation.

reach their final volume. The reaction was carried out in an iQ5 Cycler thermal cycler (Bio-Rad), with a standard protocol (initial denaturation at $95{ }^{\circ} \mathrm{C}$ for $5 \mathrm{~min}, 40$ cycles of denaturation, annealing and extension at $95{ }^{\circ} \mathrm{C}$ for $30 \mathrm{~s}, 64{ }^{\circ} \mathrm{C}$ for HPRT and IL-10, at $62{ }^{\circ} \mathrm{C}$ for TNF- $\alpha$ for $1 \mathrm{~min}$ and $72{ }^{\circ} \mathrm{C}$ for $15 \mathrm{~s})$.

\section{Statistical analysis}

The factor of change in the relative mRNA expression of HPRT, IL-10 and TNF- $\alpha$ was calculated using the 2- $\Delta \triangle \mathrm{Ct}$ method by Livak and Schmittgen (2001). The $\Delta \mathrm{Ct}$ was obtained by subtracting the $\mathrm{Ct}$ from the endogenous gene minus the $\mathrm{Ct}$ of the genes of interest (IL-10 and TNF- $\alpha$ ). The $\Delta \Delta \mathrm{Ct}$ values were presented as the mean \pm the standard error. The significances of the expression levels between the control group and the treatments were determined by means of an ANOVA and then the means were separated with Tukey's range test $(p<0.05)$ using SAS ver 10 software.

\section{RESULTS}

Results show that the seed remnants that make up the chia harvest residue contribute between $46.52,49.42,52,33$ and $53.82 \%$ of Omega- 3 fatty acids in the diets with $10,20,30$ and $40 \%$ chia residue content, respectively, while the Omega- 6 content is $9.92,10.16,11.33$ and $12.74 \%$ for the same diets (Table 4). In the case of the control diet, only trace levels of this fatty acid were identified.

For the RT-qPCR, standard curves were obtained that comply with the parameters to accept the oligonucleotides designed for the HPRT, IL-10 and TNF- $\alpha$ genes, with minor standard error equal to 0.05 of $E^{2}$ value, a slope near -3.32 and PCR efficiency of approximately $2.0 \mathrm{E}=(10-1 /$ curve $)$. The correlation coefficient $\left(R^{2}\right)$ for the standard curves 


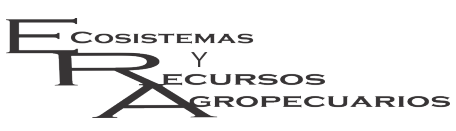

of the cytokines (IL-10 and TNF- $\alpha$ ) and for the housekeeping gene (HPRT) was greater than 0.98, which represents a linear relationship between the crossing point ( $\mathrm{CP}$ ) and the logarithm of the RNA concentration (Table 3 ).

The analyses of the gene expression of the genes (IL-10 and TNF- $\alpha$ ) related to the inflammatory process are shown in Figure 1 . These results indicate a significant increase $(p<0.05)$ in the IL10 gene in the treatments fed with a diet of 30 and $40 \%$ chia residue with values of 2.81 and 22.4 , with respect to the control, while for the treatments fed with 10 and $20 \%$ the increase in the IL- gene 10 was not significantly different from the control treatment with mRNA expression units of 1.02 and 1.49 respectively (Fig. 1A).

The mRNA expression of the TNF- $\alpha$ gene was inversely proportional as the percentage of chia residue in the treatments decreased. Thus, the highest mRNA expression of the TNF- $\alpha$ gene was found in the control diet feed with expression values of 7.49 ( $p<0.05)$, while in the diet containing $40 \%$ chia residue the expression was significantly lower $(p<0.05)$, but it is enough to add $10 \%$ chia residue to the total diet to achieve inhibition of the gene to almost a third of the mRNA expression of the control group where no chia residue was added (Fig. 1B).

\section{DISCUSSION}

Polyunsaturated fatty acids found in CSR, even when it is a waste, contain a higher proportion of Omega-3 (ALA: $\alpha$-linolenic acid, 18:3w3) than Omega-6 (LA: linolenic acid, 18:2w6). Similar studies carried out using chia seed as the main source of fatty acids have found that the seed contains between 25 to $40 \%$ fatty acids, of which $60 \%$ corresponds to Omega-3 and 20\% to Omega- 6 polyunsaturated acids (Jiménez et al. 2013; Sierra et al. 2015). One of the important functions of the Omega- 6 and Omega-3 polyunsaturated fatty acids is that both are precursors of molecules called "eicosanoids", which have important functions in the regulation of the inflammation process (Patter-
Jiménez-Rojas et al. Chia induces cytokines in rabbits Ecosist. Recur. Agropec. 5(13):35-43,2018

son et al. 2012). The eicosanoids derived from Omega- 6 include prostaglandins and leukotrienes, products of arachidonic acid metabolish, which are potent mediators in various physiological and pathological processes, inducing inflammation (Greene et al. 2011). The enzyme families cyclooxygenase (COX) and lipoxygenase (LOX) are responsible for the metabolism of arachidonic acid; these enzymes are the molecular targets of drugs for the treatment of pain, inflammation, asthma, and allergies. On the other hand, the eicosanoids derived from Omega3 are EPA and DHA, products of eicosapentaenoic acid metabolism. The mode of action for these eicosanoids includes binding to a receptor coupled to a specific $G$ protein, which allows the development of agonists and receptor-specific antagonists; these eicosanoids have important functions in the antiinflammatory process (Dennis and Norris 2015).

Changes in the $n-6: n-3$ intake ratio with an increase in $n-6$ can increase chronic inflammatory diseases such as heart disease, diabetes, obesity, asthma and rheumatoid arthritis, among others (Patterson et al. 2012). It is important to point out that a double bond in the structure of omega- 3 ( $\alpha$-linolenic acid) is the substantial factor to obtain the anti-inflammatory effect, largely due to its incorporation into cell membranes (Arita et al. 2005).

Increasing CSR inclusion levels regulated the expression of the anti-inflammatory protein gene (IL-10) and inhibited the expression of the proinflammatory protein gene (TNF- $\alpha$ ) in the colon tissue of rabbits, whereas the expression of the TNF$\alpha$ gene increased in the control treatment where there is no CSR presence. Inflammation of intestinal tissue is characterized by the infiltration of $\mathrm{M} 1$ and $\mathrm{M} 2$ type macrophages, with the M1 macrophages being stimulated by INF $\gamma$ and LPS to express proinflammatory cytokines such as TNF$\alpha$ IL-6, IL-8, IL-23, IL-1 $\beta$, and reactive species, whereas M2 macrophages are activated by IL-4 and IL-13 to express anti-inflammatory factors such as IL-10, TGF $\beta$, IL-1 receptor antagonist- $\alpha$, IL-4 and arginase (Kalupahana et al. 2011). The expression of the IL-10 and TNF- $\alpha$ genes in rabbits with induced colitis was because the toxins of the bacteria 
of the species Clostridium sp. acted in the cells of the intestinal epithelium, causing tissue detachment and necrosis to break the protective barrier of the mucosa (Solomon et al. 2013).

The host must respond quickly to avoid further cell damage and the spread of toxins to the bloodstream. Epithelial cells intoxicated with Clostridium sp. produce proinflammatory mediators such as TNF- $\alpha$ and the inflammatory protein of macrophage 2 , to initiate an inflammatory response of the intestinal mucosa (Kühl et al. 2015). All this underlies the benefits provided by CSR, an agricultural waste that can be used as animal feed, with benefits to the health of domestic animals, and provides a source of omega 3 of plant origin.

\section{CONCLUSIONS}

All the diets had high percentages of polyunsaturated fatty acids of the Omega-3 type rela- tive to the Omega- 6 type. The diets with 30 and $40 \%$ CSR had the highest level of expression of the anti-inflammatory protein (IL-10). This indicates that the CSR contains significant concentrations of $\alpha$-linoleic acid in the formulated diets, allowing for greater gastrointestinal health in rabbits, by stimulating a greater response of the immune system and conferring greater response to the effect of colitis caused by Clostridium sp. The use of CSR is recommended because of its low animal feed production cost and because of its high content of Omega-3 polyunsaturated fatty acids. The designed oligonucleotides (IL-10 and TNF- $\alpha$ ) can be used for future studies with this animal model.

\section{ACKNOWLEDGEMENTS}

The authors thank the Tecnológico Nacional de México for funding projects 5306.14-P and CONPYR-2015-0063.

\section{LITERATURE CITED}

Arita M, Bianchini F, Aliberti J, Sher A, Chiang N, Hong S, et al. (2005) Stereochemical assignment, antiinflammatory properties, and receptor for the omega-3 lipid mediator resolvin E1. Journal of Experimental Medicine 201: 713-722.

Best EL, Freeman J, Mark H, Wilcox MH (2012). Models for the study of Clostridium difficile infection Gut Microbes 3: 145-167

Capitani MI, Spotorno V, Nolasco SM, Tomas MC (2012) Physicochemical and functional characterization of by-products from chia (Salvia hispanica L.) seeds of Argentina. Lwt-Food Science and Technology 45: $94-102$.

Coates W, Ayerza R (1996) Production potential of chia in northwestern Argentina. Industrial Crops and Products 5: 229-233.

De Blas C, Mateos G (2010) Feed formulation. In: De Blas C, Wiseman J (Eds.). Nutrition of the rabbit. 2 ed. Wallingford, CAB International. UK. pp: 222-232.

Dennis EA, Norris PC (2015) Eicosanoid storm in infection and inflammation. Nature Reviews Immunology 15: 511-523.

Godornes C, Leader BT, Molini BJ, Centurion-Lara A, Lukehart SA (2007) Quantitation of rabbit cytokine mRNA by real-time RT-PCR. Cytokine 38: 1-7.

Greene ER, Huang S, Serhan CN, Panigrahy D (2011) Regulation of inflammation in cancer by eicosanoids. Prostaglandins \& Other Lipid Mediators 96: 27-36.

Halim R, Danquah MK, Webley PA (2012) Extraction of oil from microalgae for biodiesel production: A review. Biotechnology Advances 30: 709-732. 
Heuer B, Yaniv Z, Ravina I (2002) Effect of late salinization of chia (Salvia hispanica), stock (Matthiola tricuspidata) and evening primrose (Oenothera biennis) on their oil content and quality. Industrial Crops and Products 15: 163-167.

Hutton ML, Mackin KE, Chakravorty A, Lyras D (2014) Small animal models for the study of Clostridium difficile disease pathogenesis. Fems Microbiology Letter 352: 140-149.

Jeong SK, Park HJ, Park BD, Kim IH (2010) Effectiveness of Topical Chia Seed Oil on Pruritus of End-stage Renal Disease (ESRD) Patients and Healthy Volunteers. Annals of Dermatology 22:143-148.

Jiménez P, Masson L, Quitral V (2013) Composición química de semillas de chía, linaza y rosa mosqueta y su aporte en ácidos grasos omega-3. Revista Chilena de Nutrición 40:155-160.

Jun-Ming Z, Jianxiong AN (2007) Cytokines, Inflammation and Pain. International Anesthesiology Clinics 45: $27-37$.

Kalupahana NS, Claycombe KJ, Moustaid-Moussa N (2011) (n-3) Fatty Acids Alleviate Adipose Tissue Inflammation and Insulin Resistance: Mechanistic Insights. Advances in Nutrition 2: 304-316.

Komprda T, Zornikova G, Rozikova V, Borkovcova M, Przywarova A (2013) The effect of dietary Salvia hispanica seed on the content of n-3 long-chain polyunsaturated fatty acids in tissues of selected animal species, including edible insects. Journal of Food Composition and Analysis 32: 36-43.

Kühl AA, Erben U, Kredel LI, Siegmund B (2015) Diversity of intestinal Macrophages in inflammatory Bowel Diseases Frontiers in Immunology 6: Article 613.

Livak KJ, Schmittgen TD (2001). Analysis of Relative Gene Expression Data Using Real-Time Quantitative $P C R$ and the 2- $\triangle C T$. Method 25: 402-408.

Martínez GM (2013) Ensayo exploratorio: obtención de leche caprina funcional a partir de la suplementación con Salvia hispanica (Chía) RIA. Revista de Investigaciones Agropecuarias 30: 305-311.

Patterson E, Wall R, Fitzgerald GF, Ross RP, Stanton C (2012) Health Implications of High Dietary Omega-6 Polyunsaturated Fatty Acids. Journal of Nutrition and Metabolism 2012: Article ID 539426.

Peiretti PG, Meineri G (2007) Fatty acids, chemical composition and organic matter digestibility of seeds and vegetative parts of false flax (Camelina sativa L.) after different lengths of growth. Animal Feed Science and Technology 133: 341-350.

Raeburn CD, Sheppard F, Barsness KA, Arya J, Harken AH (2002) Cytokines for surgeons. American Journal of Surgery 183: 268-273.

Radonic A, Thulke S, Mackay IM, Landt O, Siegert W, Nitsche A (2004) Guideline to reference gene selection for quantitative real-time PCR. Biochem Biophys Res Commun 313: 856-862.

Ramírez G, Rosado G, Castellanos R, Chel L (2012) Potencial productivo para el cultivo de chía (Salvia hispanica L.) en México y calidad del aceite extraído. Revista de la Facultad de Ingeniería Química 52: 32-36.

Rodríguez-Abello D, Ramirez-Aviles L, Navarro-Alberto J, Zamora-Bustillos R (2016) Performance of growing rabbits fed increasing levels of discarded Salvia hispanica L. (chia) seed. Tropical Animal Health and Production 48: 959-965.

Solomon K (2013) The host immune response to Clostridium difficile infection. Therapeutic Advances in Infectious Disease 1: 19-35. 
Sierra L, Roco J, Alarcon G, Medina M, Van Nieuwenhove C, de Bruno MP, Jerez S (2015) Dietary intervention with Salvia hispanica (Chia) oil improves vascular function in rabbits under hypercholesterolaemic conditions Journal of Functional Foods 14: 641-649.

Zhang JM, An J (2007) Cytokines, inflammation and pain. International Anesthesiology Clinics 45: 27-37. 
